\title{
Musings on museology
}

\section{MARZia VARUTti}

In less than fifty years, museology has gone from a niche topical study area, subservient to a range of other disciplines - history, art history and anthropology to mention but a few - to a flourishing, multifaceted field of research and practice. Assessing what museology is today, is as challenging as assessing what a museum is. Since their inception, as public institutions at the heart of European nationalism and imperialism, museums have showed a remarkable ability to transform themselves, adapting to changing societal conditions and needs. After decades of decline, the renaissance of museums in the second half of the 20th century is evidence of their resilience: museums have turned out to be surprisingly well suited to neoliberal agendas advocating the commodification of culture, the personalization of the cultural offer, and the creation of social status linked to cultural consumption. Reflecting the changes affecting museums, museology - which I understand here as the study of museums in its broader sense - has undergone changes in virtually all its facets. Below, I briefly consider some of these.

The topics and concerns of museology have changed, mirroring the expansion of exhibition themes. If exhibitions have become artworks, constantly forging new narrative, visual, emotional and sensorial paths to meaning, they have also turned into powerful activist statements, tackling contested and debated issues, from social inequalities and discrimination to climate change, from disability to sexual, religious, and political choices. This signals that - importantly at this moment - exhibitions and museums have become spaces for reflection: they offer to the general public a chance for reflecting upon the transformations occurring in our societies.

In a similar way, museology, with its propensity for critical analysis, is an even more dedicated realm for reflexion and interpretation: it is a field where the discussion of common concerns (and delights!) can extend and deepen (in academic publications, events, pedagogy and exhibitions) to eventually engender new questions and ideas that can feed back into museum work. As museology scholars, we enjoy the privilege of critical distancing, we toy with comparative perspectives and, at our best, we reach for new, deeper insights inspired by a concept, a theory or a practice - James Clifford's (1997) seminal "museums as contact zones" being a notable example. Museology offers us a tool to make sense of the worlds we inhabit; this seems noteworthy, at times where communication and dissemination are increasingly - alarmingly - based on a few dozens character-tweets and decontextualized Instagram images.

As we know, museology is not a discipline, but a field of research at the intersection of different disciplines and professions. Multidisciplinarity is inscribed in the very essence and origins of museology, and it is thanks to the increased collaboration across disciplines and professional fields that new paths to research and practice are being opened. For instance, exhibition-making 
148 can be a tool for research, as suggested by Nicholas Thomas (2010) among others. There is potential for a fruitful circularity, whereby the set-up of exhibitions becomes fieldwork (research is being conducted at the same times as the exhibition is being created, and findings emerge as part of the process), and in turn the outcomes of collaborative research between academics and museum professionals can take the form of an exhibition, informed by research findings, now materialized, visualized and popularized for wider audiences.

An often understated, yet consequential aspect of museology is pedagogy. Museological thinking has a direct societal impact (on the museum world, and on how society at large understands museums) through teaching activities. In the Nordic countries in particular, we see a flourishing offer of museology courses and training, notably at master and doctoral level. These courses are sought after precisely because of their multifaceted disciplinary components and professional versatility, as museology does not primarily aim to form curators, conservation experts, or art connoisseurs, but thinkers able to apply critical skills to a broad range of museum aspects.

But museology also has its national variants. As an Italian moving from Francophone Switzerland to the UK, and subsequently to Norway, I have been intrigued by the slight changes in the understandings of museology from one country to the other. Long established in the UK as "museum studies", across the Channel, in France and Switzerland, "muséologie" has been associated with conservation studies, and in Italy the emphasis has been on the preservation of the artistic and architectural patrimony. Even though different nuances makes it sometimes a little more arduous for museologists to talk to each other in international meetings, this plurality of approaches is yet another testimony to the richness of this field of study.

In this international framework, the Nordic museological tradition occupies a prominent position. With its unique history of folk and open air museums and its depth of research on the historical construction of cultural knowledge in museums, the Nordic context deserves its own distinctive museological voice. Its uniqueness has been made visible through the articles published in the Journal of Nordic Museology over the past 25 years; these articles give substance to the imagined community of museum practitioners and scholars across the Nordic countries, whilst at the same time providing a portal for an expanding international readership.

Even though we might be at times unsure about what "Nordic" means (this term will no doubt continue to generate discussions), it is nevertheless an extraordinary framing device: "Nordic" captures a potential. Much more than just denoting a regional variant of museology, "Nordic museology" lends legitimacy and visibility to scholarship and museum-related initiatives that place themselves in a special relationship with local histories, people, collections and resources. This scholarship and initiatives need to be sustained and encouraged. Museology has devoted much attention to national heritages - how they are created, reinvented, used and misused (this is evidenced by the extensive literature on museums and nationalism). In all this, the focus has largely been on the content of national histories and heritage; yet there are also distinctive ways of presenting, interpreting, curating and disseminating those histories and heritage. We should cherish and celebrate the uniqueness of local Nordic approaches to heritage and museological forms as they are cultural artefacts in their own right: they also speak 
about our past and our identities, and are worthy of being displayed, shared, circulated, and preserved. This is exactly what the Journal of Nordic Museology has been doing since its first issue; the Journal has become, in a way, an archive and a living museum for Nordic museology.

But what lies ahead? We live in a world of information overload, we struggle with too many choices among quality, quantity and sources of information, unbounded in time and place. In this situation, we will increasingly need filters, compasses for navigation, and havens for reflection. Museums and museology can provide some answers to those needs. But moving in this direction entails a reformulation of the traditional forms of authority of museums, based on scientific knowledge: museums can no longer be content with disseminating accurate, reliable knowledge, nor can they limit themselves to facilitating the production of informed opinions for their audiences, or acting as platforms for dialogue - other media are better suited to perform those tasks. Both museums and museologists can take courage in positioning themselves in and above debates, forging for themselves a new role as ethical stewards, able to provide directions to navigate times and themes where ethical values are blurred, questioned and opened up for debate.

Statistics tell us that museum visits increase dramatically after traumatic events (as in the case of the 9-11 attacks in New York). It doesn't seem far-fetched to think that, in addition to ethical guidance, we will increasingly turn to museums for the solace of Beauty and a space for dreams, for respite from life's hardships and demands, and a place for healing - a place that equally encourages contemplation and social bonding. Developing this kind of moral and social stewardship will likely entail concerted efforts, based on consultation among museum professionals and scholars, and with society at large, in order to negotiate specific ethical stances. Museums and museology should be challenged to rise to those needs. Here again, the "Nordic" model and its values might be an asset in the formulation of new directions for Nordic and other museologies.

\section{LITERATURE}

Clifford, James. 1997. "Museums as contact zones." In Routes: Travel and Translation in the Late Twentieth Century. Cambridge Mass.: Harvard University Press.

Thomas, Nicholas. 2010. "The museum as method." Museum Anthropology 33:1, 6-10.

Marzia Varutti, Associate Professor of

Museology

marzia.varutti@ikos.uio.no

Centre for Museum Studies

IKOS

Postboks 1010 Blindern

N-0315 Oslo, Norway 